\title{
JOGOS TEATRAIS NA FORMAÇÃO DE LEITORES: UMA EXPERIÊNCIA NO ENSINO MÉDIO
}

Antonia Alice Queiroz BEZERRA

Maria Valdenia da SILVA

\section{RESUMO}

Os Jogos Teatrais podem ser fundamentais para o surgimento de novas propostas de leitura na sala de aula, quando aliados à formação de leitores podem favorecer a aprendizagem e motivar a leitura do texto literário. O presente trabalho tem como objetivo relatar uma experiência aplicada a uma turma de segundo ano na Escola de Ensino Médio Francisca Pinto dos Santos, no município de Ocara-ce. A partir dos Jogos Teatrais de Viola Spolin, elaboramos quatro oficinas de leitura da obra O Santo e a Porca, de Ariano Suassuna, centralizando o uso dos jogos nessas oficinas e suas respectivas consequências para a formação de leitores. Para isso, utilizamos como referencial teórico Spolin (2008), Cosson (2006), Leite (2016), entre outros.

PALAVRAS-CHAVE: Jogos Teatrais; Educação; Formação de Leitores.

\section{THEATER GAMES IN READERS DEVELOPMENT: AN EXPERIMENT IN SECONDARY SCHOOL}

\section{ABSTRACT}

Theater Games can be fundamental to the appearance of new proposals for reading in the classroom; when allied to readers' development, it might favor learning and motivate literary text reading. This work aims at reporting an experiment implemented in a second year class in the Francisca Pinto dos Santos Secondary School, in the city of Ocara, State of Ceará. From Viola Spolin's Theater games, we formulated four reading workshops with the book O santo e a Porca (The Saint and the Sow) by Ariano Suassuna, concentrating the use of games in these workshops and their related consequences to readers' development. For this purpose, we used, among others, Spolin (2008), Cosson (2006) and Leite (2016) as theoretical reference.

KEYWORDS: Theater Games; Education; Readers' Development.

\section{JUEGOS TEATRALES EN LA FORMACIÓN DE LECTORES: UNA EXPERIENCIA EN LA ENSEÑANZA SECUNDARIA}

\section{RESUMEN}

Los Juegos Teatrales pueden ser fundamentales para la aparición de nuevas propuestas de lectura en el aula, cuando aliados a la formación de lectores pueden favorecer el aprendizaje y motivar la lectura del texto literario. Este trabajo tiene como objetivo informar una experiencia aplicada a una clase de segundo año en la Escuela Secundaria Francisca Pinto dos Santos, en la ciudad de Ocara-CE. De los juegos teatrales de Viola Spolin, diseñamos cuatro talleres de lectura de la obra El santo y la cerda, de Ariano Suassuna, centrándonos en el uso de juegos en estos talleres y sus consecuencias para la formación de lectores. Para ello, utilizamos como referencia teórica Spolin (2008), Cosson (2006), Leite (2016), entre otros.

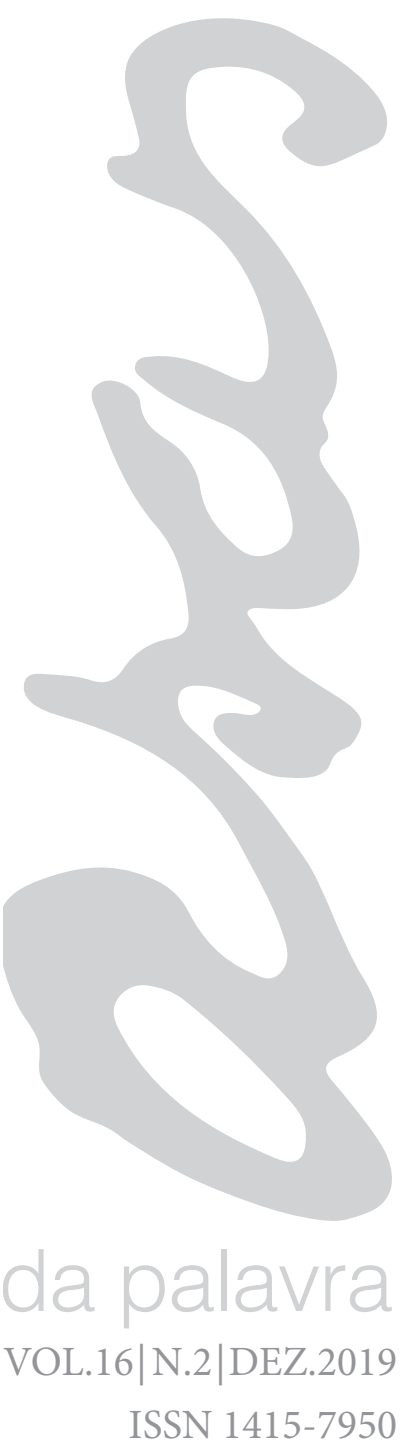

PALABRAS CLAVE: Juegos teatrales; Educación; Formación de lectores. 


\section{INTRODUÇÃO}

Nas escolas, de forma geral, podemos observar que os espaços de encontro com o teatro, geralmente, acontecem quando a atuação se torna necessária em eventos, datas comemorativas ou festejos. Nesses momentos, o texto teatral é visto simplesmente com o propósito da encenação teatral na sua forma de entretenimento; um trabalho de leitura crítica e discussão sobre o próprio texto dramático como gênero literário é completamente ignorado e a encenação realizada não busca um desenvolvimento de técnicas teatrais ou um trabalho mais próximo à arte dramática. Tem-se a impressão de que a elaboração de um espetáculo escolar não necessita de um trabalho teatral elaborado, criando a falsa ideia de que é simples e não precisa de tanto esforço. Seria esta a origem do preconceito com os artistas e com a arte? Propor a leitura do texto teatral na sala de aula é reconhecer sua importância social e compreender sua relação com as artes e o fazer teatral. O processo de leitura do texto não acaba na decodificação e interpretação do mesmo, ele necessita da exploração de outras formas de leitura, pois sua particular relação com o teatro possibilita que o texto se construa também no corpo do ator e do leitor.

O presente trabalho integra a dissertação intitulada $O$ texto teatral de Ariano Suassuna na formação de leitores no ensino médio: o corpo do texto no corpo do leitor, defendida no Mestrado Interdisciplinar em História e Letras, na qual buscamos utilizar o texto teatral de Ariano Suassuna para a formação de leitores, trabalhando com os jogos teatrais como metodologia. Na referida pesquisa, aplicamos quatro oficinas de leitura em uma escola de ensino médio e, para a elaboração destas, os jogos teatrais foram de suma importância. As oficinas foram elaboradas tendo como base as sequências básica e expandida de Rildo Cosson (2006) e aplicadas em uma turma de segundo ano do Ensino Médio, da Escola de Ensino Médio Francisca Pinto dos Santos, durante quatro aulas de Língua Portuguesa do quarto semestre do ano de 2018, o equivalente a quatro horas aula, cada uma com 50 minutos.

A metodologia adotada foi exposta por meio de oficinas. Para um trabalho mais efetivo, dividimos em quatro momentos, são estes: Oficina I- Motivações para a leitura; Oficina II- A leitura no corpo do leitor; Oficina III- Interpretar é ler o texto no corpo; Oficina IV - Outras possibilidades de interpretação no corpo do leitor. Inicialmente, as 
anteriormente na turma, como a dificuldade de ler em voz alta. No entanto, as oficinas sofreram adaptações durante a aplicação, fato que corrobora a necessidade que o educador ou educadora tem de flexibilizar suas ações relativas à mediação da leitura, visando a uma experiência significativamente eficaz do letramento literário na escola.

\section{TEATRO, JOGOS TEATRAIS E LEITURA}

Etimologicamente, o termo teatro tem sua origem no latim theatrum e pode significar "Arte de representação em palco" ou "Lugar onde se representam obras dramáticas ou líricas, comédias, revistas". No entanto, foram os egípcios que iniciaram as apresentações em público, em sua maioria, para a exaltação da mitologia egípcia, principalmente Hórus, Osíris e Ísis. Na Grécia, as manifestações teatrais foram registradas em pinturas em cavernas e na decoração de artefatos. Aproximadamente no século VI a.C., envolto aos cultos Dionisíacos, o teatro se constituía nas festividades comemorativas, na adoração aos deuses e nos ritos religiosos, sempre permutado as outras manifestações, como a dança e a música. Com a expansão desses movimentos para Roma, o teatro passou a ser reconhecido como uma representação. Essa concepção foi se difundindo nas mais variadas culturas, chegando por fim ao Oriente.

Conforme Massaud Moisés (2000) podemos observar que o teatro pode ser considerado uma das manifestações artísticas mais antigas, pois, antes mesmo da escrita, ele já estava presente nos rituais de dança e festividades do homem primitivo. Nota-se, assim, que a relação mística sempre esteve envolta nessa arte, seja relacionada a uma manifestação cultural específica voltada a comemorações e lazer, seja ligada aos elementos místicos que compõem a religiosidade de um povo. Diante de todas as transformações pelas quais o teatro passou ao longo dos séculos, podemos destacar as influências estrangeiras, as mudanças de concepções, ora centradas no texto, no diretor, ora no ator, e a criação de espaços específicos para a encenação, bem como o uso de novos materiais e tecnologias.

Nota-se que a função social do teatro também foi se modificando, desvencilhando-se de antigas concepções para dar novos lugares às ideias do mundo contemporâneo. Para Calzavara (2009, p. 150), "O drama é a mais social de todas as formas de arte. Ele é por sua própria natureza uma criação coletiva que presentifica 
o instinto do jogo na condição humana". Compreendendo que o teatro se concretiza também a partir do texto dramático, podemos perceber ambos como espaços que criam possibilidades para a realização do jogo, ou seja, é possível associar a sua importância social à necessidade humana de desenvolver práticas lúdicas, como Aristóteles aponta em A poética (1987), destacando também a importância do enredo para a tragédia. Alcione Araújo (2009, p.17) aponta para o fato de que "a expressão teatral está tão profundamente imbricada na natureza humana e na condição humana, que é quase impossível estabelecer a fronteira entre uma atividade genuína genérica e a noção de teatro", afinal, nossas ações diárias são expressões que, de uma forma ou de outra, podem ser consideradas ações teatrais, ora choramos exageradamente para conseguir algum benefício ou para expressar sentimentos, ora nossas atitudes são movidas em função de um complexo de "parecer ser" algo ou alguém, não no sentido negativo da expressão, mas no sentido de atuar para nos tornar quem somos, agindo para reafirmar o que queremos ser.

No Brasil, o teatro passou por um longo processo de transformação, desde as suas manifestações até as ideologias refletidas nas próprias obras. O fato é que o texto dramático, assim como a literatura de forma geral, está diretamente relacionado ao seu contexto de produção. Para Zilá Bernd (1992), existe uma literatura sacralizadora que corrobora e contribui para os pensamentos de uma determinada época e uma perspectiva dessacralizadora que busca refletir e desconstruir as ideologias dominantes em determinados períodos históricos.

No século XIX, o foco do teatro era uma leitura e interpretação de suas manifestações a partir da crítica à qualidade estética do texto escrito, os outros elementos eram observados em segundo plano, como a performance dos atores. Ao longo desse mesmo século, visto como vanguarda e apontando temáticas sociais, o teatro realista começou a se fazer presente, do qual destacamos $O$ demônio familiar (1857) e Mãe (1860), de José de Alencar, os quais trataram da escravidão. Apesar do teatro realista iniciar as discussões sociais, a crítica e a maior parte das peças buscavam defender uma ideologia da moral baseada na conservação de valores e padrões burgueses e do que se compreendia na época como bons costumes, uma espécie de teatro educativo, este último não no sentido emancipatório de Paulo Freire, mas na concepção dominadora e manipuladora de ideais e posturas, principalmente para o público infantil. 
Numa dimensão mais abrangente, o Teatro é a arte que faz uso do texto dramático ou teatral, mas não apenas deste. A definição contemporânea dessa arte não é consenso e a cada dia ganha novas possibilidades de interpretação. Para Jerzy Grotowski (1992), o teatro seria o que acontece entre o espectador e o ator, a comunicação que ocorre no ato da encenação e, por isso, Grotowski concebe como essencial uma maior participação do público em suas peças. Enquanto para Peter Brook (2008), as ações teatrais ocorrem não a partir de dois elementos, mas de três, além do espectador e do ator, ele acrescenta o espaço vazio, o qual possibilitaria o fazer teatral nas suas múltiplas formas. $\mathrm{O}$ fato é que essas e outras concepções influenciam o fazer teatral e a forma como este se faz presente nos mais diferentes ambientes sociais. Propor a leitura do texto teatral na sala de aula é reconhecer sua importância social e compreender sua relação com as artes, com o fazer teatral.

$\mathrm{O}$ processo de leitura do texto não acaba na decodificação e interpretação do mesmo, ele necessita da exploração de outras formas de leitura, pois sua particular relação com o teatro possibilita que o texto se construa também no corpo do ator e do leitor. Compreendendo tais especificidades do texto dramático, torna-se essencial afirmá-lo em sua relação com os estudos teatrais. Neste caso, aproximaremos o mesmo dos jogos dramáticos desenvolvidos por Viola Spolin (2008), objetivando a formação de leitores capazes de perceber esse gênero como ligado à teatralidade. De acordo com Sarrazac:

A teatralidade é aquilo que permite pensar o teatro não sem o texto mas, de modo recorrente, a partir de sua realização ou seu devir cênico. (...) Mas, sobretudo, vontade de libertar o teatro de sua identidade literária, abstrata e atemporal, para recuperar sua abertura para o mundo, para o real. Nesse sentido, a teatralidade reinstitui a arte do teatro enquanto ato. (SARRAZAC, 2013, p. 15)

Nessa perspectiva de compreensão do texto, consideramos que é essencial abarcar também a educação como experiência. Jorge Larrosa (2014) nos inquieta, apontando os benefícios e as transformações que são possíveis ao reconhecer a vida como experiência, para assim aproximar o processo educacional de vivências mais naturais.

A vida como experiência, é relação: com o mundo, com a linguagem, com o pensamento, com os outros, com nós mesmos, com o que se diz e o que se pensa, com o que já estamos deixando de ser. A vida é a experiência da vida, nossa forma singular de vivê-la. Por isso, colocar 
a relação educativa sob a tutela da experiência (e não da técnica, por exemplo, ou da prática) não é outra coisa que enfatizar sua implicação com a vida, sua vitalidade. (LARROSA, 2014. p. 74)

Desconstruindo uma visão tradicional, para além de sugerir algo diferente, o pesquisador propõe que esse reconhecimento das experiências nos possibilita negar o que é imposto, mostrando possibilidades de existência, de vivência. Ao discutir experiência, Larrosa (2014) suscita a seguinte reflexão:

Fazer soar a palavra 'experiência' em educação tem a
ver, então, com um não e com uma pergunta. Com um
não a isso que nos é apresentado como necessário e como
obrigatório, e que já não admitimos. E com uma pergunta
que se refere ao outro, que encaminha e aponta em
direção ao outro (para outros modos de pensamento, e da
linguagem, e da sensibilidade, e da ação, e da vontade),
porém, sem dúvida, sem determiná-lo. (LARROSA,
2014. p. 74)

Pensando a sala de aula sob essa compreensão, o trabalho com o texto teatral nos impulsiona a reconhecer os processos como experiências. Nas leituras das peças teatrais (referimo-nos à leitura como algo múltiplo: montagens, performances, etc.), é fundamental estabelecer conexões com a própria vivência, para descentralizar o foco na obrigatoriedade de uma apresentação final, reconhecer a importância do processo, o qual poderíamos denominar experiência ou caminhar da experiência. Como afirma Larrosa (2014, p.74), "deixar que a palavra "experiência" nos venha à boca (que tutele nossa voz, nossa escrita) não é usar um instrumento, e sim se colocar no caminho, ou melhor, no espaço que ela abre".

Por conseguinte, a elaboração de propostas para a sala de aula deve considerar a relação que o tex to pode vir a estabelecer com o corpo e como essa relação pode contribuir para a formação de leitores. Em nossas experiências de sala de aula, ouvimos relatos de estudantes que dizem jamais esquecer determinadas obras literárias, porque as vivenciaram no próprio corpo, porque a literatura, compreendida e transformada em experiência, atravessa a própria vivência humana e sensibiliza. Diante disso, surge o seguinte questionamento: como proporcionar essas vivências no corpo apenas através da leitura? Para responder a essa questão, enfatizamos a necessidade de aliar a leitura do texto aos jogos 
de ferramentas que contribuam efetivamente para um corpo atento e disposto às novas maneiras de ler e interpretar. O jogo é o elemento base do teatro, é através dele que os corpos encontram possibilidades de ação, de reflexão e, principalmente, de vivência. O jogo também tem se destacado nas pesquisas sobre aprendizagem, mostrando-se efetivo no desenvolvimento de habilidades e competências dos educandos, não apenas nas séries iniciais. Segundo o filósofo Johan Huizinga:

Jogo "é uma atividade ou ocupação voluntária, exercida dentro de certos e determinados limites de tempo e espaço, segundo regras livremente consentidas, mas absolutamente obrigatórias, dotado de um fim em si mesmo, acompanhado de um sentimento de tensão e alegria e de uma consciência de ser diferente da vida cotidiana" (HUIZINGA, 2007, p. 33).

Desse modo, torna-se fundamental a presença de jogos na escola. No campo do teatro, temos os jogos teatrais desenvolvidos por autores como Augusto Boal e Viola Spolin, esta última afirma que:

O jogo é uma forma natural de grupo que propicia o envolvimento e a liberdade pessoal necessários para a experiência. Os jogos desenvolvem as técnicas e habilidades pessoais necessárias para o jogo em si, através do próprio ato de jogar. As habilidades são desenvolvidas no próprio momento em que a pessoa está jogando, divertindo-se ao máximo e recebendo toda estimulação que o jogo tem a oferecer - este é o exato momento em que ela está verdadeiramente aberta para recebê-la (SPOLIN, 2006, p.4)

Focalizando o uso dos jogos teatrais como recurso pedagógico, a pesquisadora em artes cênicas Priscila Tatiana Araújo Leite nos mostra a importância dos jogos teatrais para o desenvolvimento de crianças e jovens na escola, ela afirma que:

Logo, o teatro, dentro das mais diversas áreas de desenvolvimento humano, traz consigo a possibilidade de autoconhecimento necessário para o bom desenvolvimento do ser humano. $\mathrm{O}$ aluno de teatro passa por experiências onde é capaz de sentir suas emoções a fundo. Para a criança, o toque no outro ou no seu próprio corpo traz consigo uma carga de descobertas que, com certeza tornam a sua vida mais sensível, mais desperta, para questões tanto de cunho educativo quanto profissional, emocional, pessoal, familiar. (LEITE, 2016 , p.17)

Assim, acreditamos que, por meio da utilização dos jogos 
teatrais, podemos aproximar o tex to de Ariano Suassuna da realidade dos educandos e associá-los à formação de leitores. Além disso, trabalhando com os jogos, focalizaremos o corpo como elemento artístico e como constituinte do ser social. Pensar o corpo na sociedade contemporânea é se opor às amarras de um sistema opressor que somente o reconhece a partir de duas perspectivas: a primeira se refere ao corpo obediente, dominado e manipulado, como podemos encontrar em Foucault (1987). O autor analisa historicamente as compreensões que a sociedade foi adquirindo sobre o corpo através da sua leitura dos instrumentos de criação e manutenção de corpos adestrados para viver em sociedade. Ele aponta que as duas instituições que mais contribuíram para uma disciplina do corpo foram as escolas e os quartéis:

Esses métodos que permitem o controle minucioso das
operações do corpo, que realizam a sujeição constante de
suas forças e lhes impõem uma relação de docilidade-
utilidade, são o que podemos chamar as "disciplinas".
Muitos processos disciplinares existiam há muito tempo:
nos conventos, nos exércitos, nas oficinas também. Mas
as disciplinas se tornaram no decorrer dos séculos XVII
e XVIII fórmulas gerais de dominação. (FOUCAULT,
1987. p.164)

A disciplina militar, conforme Foucault, surgida nos exércitos protestantes, deixou marcas também na escola, como por exemplo, o posicionamento autoritário do professor que acabou se estabelecendo como um elemento fundamental para a educação, além dos castigos físicos e psicológicos dados aos estudantes que desobedeciam às regras.

Ainda hoje as práticas escolares não reconhecem o corpo como essencial no processo de desenvolvimento humano. A ideia de disciplina prevalece; educado parece ser sempre aquele que se mantém sentado e imóvel na sala de aula. Se por um lado podemos compreender uma postura disciplinar como uma forma mais sutil de manter uma determinada ordem, por outro lado, ela deixa claro que para isso é preciso a imobilidade do corpo. A sala de aula se constituiria como um laboratório onde os mais educados e "civilizados" seriam os que não se movimentassem e, portanto, conseguissem manter uma postura de gestos pequenos, breves e lentos. Esse problema está diretamente relacionado à questão da fragmentação dos saberes na escola. Edgar Morin discorre sobre a complexidade da condição humana e reflete sobre a necessidade de reconhecer o ser humano a partir das suas várias

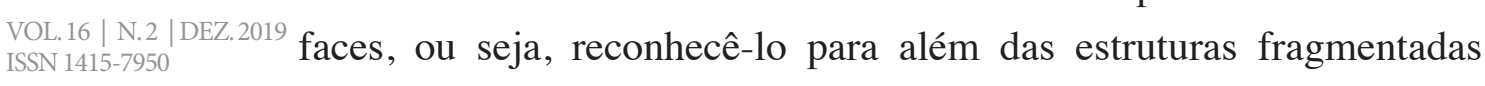


construídas socialmente.

\begin{abstract}
Seria preciso conceber uma ciência antropossocial religada, que concebesse a humanidade em sua unidade antropológica e em suas diversidades individuais e culturais. À espera dessa religação - desejada pelas ciências, mas ainda fora de seu alcance, seria importante que o ensino de cada uma delas fosse orientado para a condição humana. Assim, a Psicologia, tendo como diretriz o destino individual e subjetivo do ser humano, deveria mostrar que Homo sapiens também é, indissoluvelmente, Homo démens, que Homo faber é, ao mesmo tempo, Homo ludens, que Homo economicus é, ao mesmo tempo, Homo mythologicus, que Homo prosaicus é, ao mesmo tempo, Homo poeticus. (MORIN, 2004.p. 35)
\end{abstract}

A segunda forma diz respeito à hipersexualização dos corpos, principalmente do corpo feminino. Esse fenômeno ocorre através dos discursos divulgados pelas mídias e pela negação do diálogo familiar sobre a sexualidade. Educados sob o estigma de não poder falar sobre sua sexualidade e/ou sobre seus próprios corpos, os jovens que chegam ao ensino médio não conhecem as possibilidades do seu corpo e não o reconhecem como parte de seu ser complexo. Por isso, os exercícios propostos pelos jogos teatrais e a ludicidade envolvida na leitura de textos dramáticos contribuem para o desenvolvimento de reflexões teóricas e práticas sobre o corpo, incentivando o despertar de uma consciência para corpos ativos, capazes de atuar na sociedade a partir do autoconhecimento.

Nessa perspectiva, o texto teatral se tornaria uma base multiplicadora de possibilidades, uma vez que sua estrutura aponta diretamente para vivências do próprio corpo. Por meio do uso dos jogos dramáticos, os leitores podem desenvolver essa aproximação entre o texto escrito e a própria encenação, promovendo outras formas de leitura do texto literário. Trabalhar na perspectiva da experiência não significa "fazer de qualquer forma”, pelo contrário, a proposta é orientar as vivências da melhor maneira possível, por meio de estratégias, de sequências didáticas.

Nesse contexto, surge também a necessidade de novos olhares para o texto dramático desde a sua leitura até a forma como este adquire cada vez mais características. As mudanças pelas quais as relações que os gêneros literários passam ou não ao longo dos anos devem ser discutidas nas aulas de língua portuguesa, para que os educandos 
desenvolvam o senso crítico diante das transformações sociais, sabendo lidar com os novos diálogos intertextuais. O ambiente escolar poderia estar mais atento a esses diálogos que a leitura promove, afinal, ao propor a leitura de uma peça teatral em sala, o educador deve compreender estar disposto a elaborar uma sequência que possibilite a construção de interpretações a partir das ações dos personagens. A dramaturgia exige do leitor níveis maiores de atenção e interpretação, as emoções e as características das personagens não podem ser encontradas de forma linear como no romance. Elas estão fora dos diálogos, estão nas rubricas, nas entonações de voz e, principalmente, no corpo do ator no palco.

O texto teatral desafia o leitor a considerar e realizar a leitura de todos os seus elementos, para assim, desenvolver interpretações mais coerentes com ele. Como também nos aponta Kelly Costa (2006) ao falar das especificidades do gênero dramático.

É importante ressaltar que o texto dramático,
diferentemente da narrativa, revela o seu sentido por
meio da ação das personagens e das rubricas. Logo, o
seu estudo deve ser feito, observando principalmente
estes dois elementos. Quando realizamos uma leitura
apressada de um texto dramático, geralmente, tendemos a
desconsiderar as rubricas de modo que muitas vezes nem
as lemos, por isso o professor tem de chamar a atenção
do seu aluno para a importância de lê-las. Nas rubricas
não estão contidas apenas informações para quem irá
encenar o texto, mas também elas revelam como são as
personagens, os espaços, o tempo em que tudo acontece
no enredo, entre outros aspectos que são determinantes
para se analisar e compreender o texto como um todo
coeso. (COSTA, 2006. p. 96)

Isso ocorre, porque ele pode ser considerado um texto de caráter multimodal, como nos afirma Marega (2015, p.72): “A produção escrita desse gênero discursivo permite- nos refletir as relações entre fala e escrita; sua produção oral leva-nos a pensar em entonações e gestos que podem acompanhar as falas das personagens, seus movimentos e ações diante de um cenário proposto", ou seja, ele estabelece conexões com outras linguagens e pode contribuir para o desenvolvimento de habilidades. Neste sentido, compreendemos que essa é uma das grandes contribuições do texto dramático para a formação de leitores, ativando seus conhecimentos não apenas no campo intelectual, mas também corporal. A relação entre teatro e literatura se estabelece à medida que o primeiro dialoga com a segunda através do texto dramático. Diferente 
específicos que marcam suas fronteiras com a Literatura, é o valor estético e artístico do texto teatral que o aproxima e o torna literário. Assim, compreendemos a construção estética e as influências sociais da obra teatral de Ariano Suassuna, para apresentarmos uma proposta metodológica que contribui com a formação de leitores na escola, a partir do viés do teatro e dos jogos teatrais. Utilizamos a peça $O$ santo e a porca (2018), de Ariano Suassuna, como texto base para a proposta de letramento.

\section{A SALA DE AULA COMO ESPAÇO DE EXPERIMENTAÇÃO}

As oficinas foram aplicadas nas aulas de Língua Portuguesa da turma na qual atuamos na referida disciplina no ano de 2018. A primeira oficina, "Motivações para a leitura", partiu da ideia de introduzir o tema da avareza como motivação para a leitura da obra $O$ santo e a Porca. No primeiro momento, foi explicada a proposta de forma breve e em seguida, aplicou-se o primeiro questionário. Em seguida, iniciou-se a oficina propriamente dita com o "Jogo I - Sentindo o EU com o EU". Neste momento, toda a turma participou. Nos cinco primeiros minutos, houve uma dificuldade em ficar concentrado, o que é absolutamente normal após o horário de intervalo no qual estávamos. No entanto, ao longo das orientações, um profundo silêncio pairou sobre a turma e, a cada instrução, os estudantes movimentavam a parte do corpo citada lentamente. Observou-se que, para eles, era preciso o movimento para sentir cada parte. Passada a terceira orientação, todos estavam com os olhos fechados, como uma forma de expressar a timidez diante de algo novo. A maior dificuldade percebida neste primeiro jogo foi a de permanecer com os olhos abertos, o medo da avaliação do outro foi percebido em todos.

No segundo jogo, "Caminhada no espaço 1", afastamos as cadeiras para o fundo da sala. Apenas dez estudantes se prontificaram a participar, o restante ficou na plateia. Enquanto caminhava com os dez, os outros pareciam assustados com a ideia de estar na frente de um público. Os que caminhavam demonstraram interesse em fazer algo novo, no entanto, ao longo das instruções, foram surgindo as dificuldades e dúvidas, tudo parecia muito abstrato. O estudante ' $D$ ' disse "Como vou fazer isso?" e, em seguida, todos olhavam para mim. Era um exemplo a ser seguido, porém isso não os limitava, os movimentos por mim realizados eram apenas o pontapé inicial para os 
movimentos que eles poderiam realizar.

Durante o jogo, eles investigaram o ambiente da sala de aula completo, incluindo tocar nos que estavam na plateia. Os 10 minutos programados se transformaram em 25 minutos e, logo após, todos se sentaram e conversamos sobre o momento e o que sentiram. Neste processo, o momento de falar sobre o que foi vivido é muito importante. Nas falas, ainda um pouco impactados com a vivência, fica nítida a vontade de continuar e de entenderem o que foi vivido. A estudante ' $E$ ' disse que "Foi estranho, diferente, tive vergonha, mas quando vi que a tia tava fazendo, passou!", enquanto a educanda ' $F$ ' disse que "Não sei explicar, vi a sala diferente, não tinha tocado nas paredes antes!". A conversa durou cerca de 15 minutos.

Em seguida, realizamos uma breve introdução sobre o mundo capitalista e as estratégias de sobrevivência, sem slides, oralmente. Assim, acabamos nos detendo bastante nos jogos e, infelizmente, não houve tempo para a aplicação da segunda parte da oficina na primeira aula. Percebi que, na proposta elaborada, havia muita coisa para realizar na primeira oficina, por isso, selecionei os jogos e em seguida introduzi o tema da avareza através do debate sobre o mundo capitalista e sobre os pecados capitais. Para finalizar esse momento, com as palavras já escondidas antes da aula na sala, orientei que eles deveriam encontrar quatro palavras escondidas que se relacionam com um dos sete pecados capitais. O jogo durou uns 10 minutos, os estudantes encontraram as palavras "pão-duro", "mão-de-vaca", "unha-de-fome" e "muquirana", chegando, assim, ao tema da obra a ser lida, a avareza.

$\mathrm{Na}$ segunda aula, continuamos com foco no autor, realizando o que Cosson (2006) chama de introdução. Apresentei dois trechos do filme $O$ auto da compadecida, baseado na obra de Ariano Suassuna, para que os estudantes chegassem ao nome do autor. Para minha surpresa, todos conheciam o filme, mas ninguém sabia que era baseado em um livro, muito menos em uma peça teatral ou quem era o escritor. Expliquei aspectos centrais da vida de Ariano Suassuna, enfatizando a sua influência da Literatura de Cordel, pois a turma tinha acabado de estudar esse assunto. Em seguida, começamos com o "Jogo III personagem/ relacionamento", dando início à oficina II, intitulada "A leitura no corpo do leitor". Durante o jogo, chegamos à conclusão observada por Spolin, em suas palavras: 
pessoas nos mostram quem elas são por aquilo que dizem sobre si mesmas, mas por meio de suas atitudes. Quando chegarem a este ponto, traga o fato de que atores, para comunicar sua identidade à plateia, precisam mostrar Quem através do relacionamento com seus parceiros de jogo. 'Mostre, não conte!' (SPOLIN, 2008, p. 71)

A partir disso, explicamos que essa é uma característica do texto teatral, ele não fala sobre as personagens, ele expõe suas ações e são estas que descrevem suas características. Logo após, dividi a turma em grupos e distribuí os livros para iniciarmos a leitura da peça $O$ Santo $e$ Porca. A equipe 1 iniciou a leitura, cada integrante era um personagem e, logo no início, dois estudantes deixaram claro a importância da entonação, eles próprios chamando atenção uns dos outros. A forma de ler o texto também foi um elemento trabalhado desde o início do ano letivo, fazendo-os perceber que ler uma poesia nos exige uma postura totalmente diferente de ler uma notícia. Ficou perceptível o preconceito de dois meninos em não querer ler a fala de uma personagem mulher, Caroba, porém, após insistência dos próprios colegas, ele leu, e, mesmo ao longo da leitura, trocando de equipe, o mesmo não quis deixar a personagem. Assim, realizamos a leitura do primeiro e segundo atos, finalizando a aula do dia.

Importante ressaltar que frases marcantes de alguns personagens ficaram na memória dos estudantes. Nos corredores, um ou dois dias após a leitura, os alunos diziam "Ai, meu Santo Antonio, ai, minha porquinha!", revelando a interação que eles tiveram com a peça e como a leitura os tocou fortemente.

Os estudantes mais participativos acabaram se identificando com a personagem Eurico, tanto pela forma "aperriada" de se expressar, quanto pelas confusões nas quais ele se envolveu, sendo estas relacionadas à linguagem, confundindo assuntos e ficando atrapalhado diante da família.

$\mathrm{Na}$ aula seguinte, aplicamos a oficina III, denominada interpretar é ler o texto no corpo. Ocorreu um fato inédito para a turma, todos chegaram à sala no horário correto, ansiosos pela continuação da história. Iniciamos, porém, com a "Oficina II", que não deu tempo de ser aplicada completamente no encontro anterior. Em razão disso, começamos com o "Jogo IV - caminhada no espaço n.2". Logo no início, os estudantes afirmaram que o espaço da sala era pequeno para caminhar e sugeriram irmos para a quadra esportiva, que no momento 
estava disponível. Concordamos prontamente com a proposta, porém, de 28 pessoas presentes no encontro, apenas 12 quiseram participar deste jogo. Apesar de ocorrer dispersão neste local, a turma tem razão ao afirmar que a sala de aula acaba sendo um espaço pequeno para explorar, afinal ela possui muitas mesas e cadeiras.

A identificação com as personagens ocorreu de forma lúdica ao longo das instruções. As que foram mais aclamadas e melhor representadas foram Caroba, Eurico e Dodó. Para representar Caroba, as estudantes usaram formas corporais que se aproximavam de uma figura empoderada. Nas pausas, ficavam sempre em posição de mulher maravilha, com o braço para cima em posição de luta, ou ainda com o nariz empinado, insinuando algum respeito, enquanto os rapazes representavam Caroba, sempre rindo, como a debochar dos outros pela sua esperteza. Para as adolescentes, dar corpo à personagem foi a oportunidade de enfrentar frente a frente a postura machista dos colegas de sala, assumindo-se como protagonistas de uma história, capazes de conseguir o que querem, de enganar para favorecer a todos. Para elas, o corpo de Caroba vinha de maneira mais espontânea, como a abraçar seu próprio desejo de atuar e de ser capaz de promover mudanças em sua realidade, enquanto para eles esse corpo demonstrava um incômodo, não por ser uma mulher, mas por ser uma mulher empoderada, por isso, as garotas riam da forma como eles a representavam.

Durante a caminhada, quando representavam Eurico, inevitavelmente surgiram as expressões frequentemente ditas por ele, gerando riso e alterações no corpo, deixando-os mais soltos e menos automáticos. Os movimentos tornavam-se espontâneos, como nos diz Viola Spolin: ou uma força mística possuída pelos privilegiados somente. No entanto, todos nós tivemos momentos em que a resposta certa "simplesmente surgiu do nada" ou "fizemos a coisa certa sem pensar". Às vezes em momentos como este, precipitamos por uma crise, perigo ou choque, a pessoa "normal" transcende os limites daquilo que é familiar, corajosamente entra na área do desconhecido e libera por alguns minutos o gênio que tem dentro de si. "Quando a resposta a uma experiência se realiza no nível do intuitivo, quando a pessoa trabalha além de um plano intelectual constrito, ela está realmente aberta para aprender (SPOLIN, 2010, p.34). 
Por isso, denominamos esse momento como o auge do trabalho com o corpo nas oficinas, onde a espontaneidade alcançada demonstrou um autoconhecimento corporal que, até então, a turma não havia desenvolvido. Como explica Viola Spolin “...Os jogos teatrais vão além do aprendizado teatral de habilidades e atitudes, sendo úteis em todos os aspectos da aprendizagem e da vida". (SPOLIN, 2012, p.27).

Obviamente, esse momento só foi possível após as outras vivências, sendo resultado de um processo de consciência corporal e, para esta, o texto teatral de Ariano Suassuna teve grande contribuição. Sobre os feitos de uma boa leitura, ressalta Perissé (2006):

\begin{abstract}
A literatura nos ajuda a realizar essas descobertas descortinadoras. Descobertas feitas em diálogo com autores que jamais conheceremos fisicamente (mas que conheceremos pelo ato da leitura), [...] que devemos marcar com o rosto sério, voz pausada e grave, com quem se sente capaz de definir o destino do universo com o poder da mente. Descobertas são descobertas, no sentido mais simples da palavra: ver o que se antes não se via, e admirar-se! (PERISSÉ, 2006, p. 71)
\end{abstract}

Se a literatura possui esse poder, aliada aos jogos teatrais, ela demonstrou ter ainda mais força, possibilitando a ampliação dos sentidos da leitura na escola. Outra personagem que se destacou pela leitura que os estudantes fizeram de sua postura foi Dodó, o qual usava sempre um disfarce que o deixava bastante engraçado e estranho. Os meninos, em especial, adoraram imitá-lo e compará-lo a pessoas conhecidas de suas comunidades. O exagero nos gestos, na corcunda, na péssima aparência, gerou muitos risos e até os que estavam mais distantes se aproximaram para assistir à encenação. Aos poucos, alguns foram se sentindo à vontade para fazer interferências no corpo do outro, sugerindo posições, gestos e ações que eles poderiam fazer para representar melhor a personagem em questão. Durante todo o jogo, o riso tomava conta da plateia, Chauí (1982, p.56), não discorda de Spinosa quando afirma:

A alegria é o que sentimos quando percebemos o aumento de nossa realidade, isto é, de nossa força interna e capacidade para agir. Aumento de pensamento e de ação, a alegria é caminho da autonomia individual e política. A tristeza é o que sentimos ao perceber a diminuição de nossa realidade, de nossa capacidade para agir, o aumento de nossa impotência e a perda da autonomia. A tristeza é o caminho da servidão individual e política, sendo suas formas mais costumeiras o ódio e o medo recíprocos. (CHAUÍ, 1982, p. 56) 
Neste caso, o riso como fator de alegria expandiu os horizontes de leituras e da realidade, proporcionando uma maior interação entre os participantes. A participação da plateia, no início, deixou os jogadores um pouco constrangidos, mas com a minha participação e a aceitação da plateia, foram se soltando. Durante a representação do caminhar de Caroba, um aluno chegou a dizer "Não imaginei Caroba assim não!", uma das meninas respondeu "Eu que tô fazendo". A primeira frase reflete que eles conseguiram criar imagens das personagens, enquanto na segunda podemos identificar a força do jogo de dar autonomia aos sujeitos e os fazerem construtores do texto, de uma nova interpretação e possiblidade criativa.

Em outro momento, a plateia reclamava que alguns "Euricões" estavam muito calmos, tranquilos, afirmando que a personagem não era assim. Como resposta, um estudante disse "Olha! O da tia também é estranho!", ou seja, ao observarem as minhas ações, perceberam que não havia certo ou errado, cada um era responsável pela criação daquele corpo.

Após alguns minutos de jogos, paramos e conversamos um pouco sobre as dificuldades encontradas, como nos sentimos, e os relatos afirmaram ter sido legal e divertido, mas que no começo foi muito difícil. Em seguida, voltamos para a sala de aula e continuamos a leitura. Felizmente, concluímos a leitura ao fim da segunda aula, porém, faltou a quarta oficina ser aplicada. Por isso, adiamos, para a semana seguinte, a finalização da discussão e da interpretação do livro.

$\mathrm{Na}$ semana seguinte, começamos a oficina IV - Outras possibilidades de interpretação no corpo do leitor, com o "Jogo VIII - NÓ”. No primeiro momento, apenas 10 estudantes participaram, no entanto, quando concluímos o jogo, pediram para fazermos novamente e neste momento mais cinco resolveram participar.

O objetivo de desfazer o "nó" gerou, da primeira vez, um alvoroço enorme, mas, da segunda, houve muita concentração e conseguiram desfazê-lo, com perfeição e sem barulho. Acreditamos que esse foi o jogo que mais teve participação e concentração por parte de todos, inclusive da plateia, que ficou angustiada pelas dificuldades encontradas durante a execução do jogo.

Em seguida, já introduzimos o "Jogo VIII - Siga o seguidor", do qual apenas cinco duplas participaram, divertindo todos os outros. Enquanto algumas duplas faziam movimentos simples, outras 
exploravam o máximo possível do corpo e do espaço, dificultando a vida dos seus parceiros.

Continuando a atividade das caminhadas no espaço, retornamos às representações das personagens femininas através do corpo, buscando identificar as semelhanças e diferenças entre elas. O momento mais significativo foi o debate, no qual a turma demonstrou compreender a importância de Caroba, enquanto afirmavam que Margarida e Benona acabavam ficando sem graça, porque eram medrosas apesar de suas participações no plano. Devido ao grande tempo que levamos no jogo anterior, não tivemos condições de aplicar o último jogo, "Tocar e ser tocado".

\section{CONSIDERAÇÕES FINAIS}

A aplicação de uma proposta com elementos considerados novos gera, inevitavelmente, comentários entre os educadores e educandos. Estes últimos demonstraram interesse em atividades diferenciadas, alegando que a maioria das aulas eram paradas, cansativas e demasiadamente teóricas. Em contrapartida, as turmas que observavam a interação daquela turma específica com as etapas das oficinas realizadas durante o ano letivo questionavam os outros educadores sobre a necessidade de terem aulas semelhantes e o porquê deles também não seguirem aquela metodologia. Esse fenômeno nos faz refletir sobre o ensino, muitas vezes, fracassado no ambiente escolar, maçante, numa pedagogia tradicional, que não reconhece a complexidade dos seres humanos e a necessidade da expressão artística para aprendizado. Além disso, podemos perceber a força e impacto que uma nova proposta de atividade possui. Para além da sala de aula, mexe com a escola toda e, consequentemente, provoca mudanças.

Entre os pontos positivos encontrados no percurso desta aplicação, identificamos o contexto social no qual a referida instituição escolar está inserida, a importância dada ao resgate histórico, à preservação e recriação cultural e à luta nos movimentos sociais. Tudo isso contribuiu para que a proposta pudesse ser aceita pela comunidade escolar. A porção da realidade Manifestações Culturais, desenvolvida como estratégia pedagógica nas escolas do campo, promovia referências ao Movimento Armorial de Ariano Suassuna no sentido de preservar uma identidade cultural do Nordeste.

A avaliação que podemos fazer do uso dos jogos teatrais nesta 
experiência é que a sua utilização implicou em outras formas de ler, principalmente através do corpo, interpretando e percebendo a estrutura do texto em sua essência (os diálogos) e os personagens em suas características individuais. Acreditamos, após essa experiência, que o ato de ler por si só não é suficiente, podemos associar outras práticas a ele. Neste sentido, os jogos contribuíram, como os próprios estudantes afirmaram, para um modo de ler diferenciado, ou seja, com o corpo e na interação deste com outros. Outra vantagem de usar os jogos é que não precisamos de muitos materiais, os sujeitos e um espaço favorável já possibilita o trabalho. Aliados à leitura literária de textos teatrais, os jogos podem contribuir para a formação de leitores no ensino médio de forma significativa.

Durante as oficinas, percebemos que se concentrar na leitura ainda é um desafio para alguns, por isso a necessidade de pensar sobre ela. A leitura dos atos de $O$ Santo e a porca, em equipes, demonstrou que havia um grande desequilíbrio nos níveis de leitura dos estudantes, enquanto alguns articulavam a leitura no nível de leitores proficientes, compreendendo os significados do texto, o jogo de palavras que os levavam ao riso, outros não conseguiam acompanhar a leitura por motivos de desconcentração, executando uma leitura decodificada com extrema dificuldade.

Outra grande dificuldade, que aos poucos foi ganhando destaque nas oficinas, foi a relação dos estudantes com os seus corpos ou com os corpos dos seus colegas de classe. Adolescentes, muitos gostavam de insinuar temas sobre sexo durante as aulas, sempre de forma erotizada, demonstrando que o tema não é mais um tabu. A problemática envolve os estereótipos e a erotização dos corpos desde muito cedo. A sociedade nega o direito dos estudantes de conhecerem seus corpos e falar sobre eles por outros vieses, o da arte, da sinestesia e da própria literatura. Por isso, o corpo torna-se um elemento banalizado, sem reconhecermos a sua importância para o autoconhecimento, inclusive para a luta diante das injustiças sociais. Sendo esta última um grande foco das escolas do campo, estas, portanto, deveriam estar mais atentas a como o corpo é estudado e investigado na própria escola e no movimento que a envolve, buscando aberturas ainda maiores que estas experiências realizadas, num trabalho contínuo. Na prática, muitos possuem medo de mostrar-se em posições diferentes, medo do julgamento dos colegas. A experiência, 
da turma, tirando-os da zona de conforto vivida no ambiente escolar, principalmente através do elemento da tensão pós- leitura e pré-jogo teatral.

\section{REFERÊNCIAS}

ARAÚJO, Alcione. Do impresso à cena: o papel do teatro na formação de leitores. In: SANTOS, Fabiano dos; NETO, José Castilho Marques; RÓSING, Tania M.K (org) Mediação de leitura: discussões e alternativas para a formação de leitores. São Paulo: Global, 2009.

ALENCAR, José de. O demônio familiar. Obra completa, v. 4, 1957. , José de. Mãe (1860). Biblioteca Virtual de Literatura:[sd]. < Disponível em http://www.dominiopublico.gov.br/download/texto/bi000161.pdf $>$. Acesso em 09 de novembro de 2018.

BERND, Zilá. Literatura e identidade nacional. Porto Alegre: Universidade Federal do Rio Grande do Sul, 1992.

CALZAVARA, Rosemari Bendlin. Encenar e ensinar: o texto dramático na escola. R.cient./FAP, Curitiba, v.4, n.2 p 149-154, jul/ dez. 2009. Disponível em: https:// www.yumpu.com/pt/document/view/14612029/encenar-e-ensinar-o-textodramatico-na-escola-fap. Acesso em 09 de novembro de 2018.

CHAUÍ, Marilena. Morte e vida do educador. In: BRANDÃO, Carlos Rodrigues. $O$ Educador, vida e morte: escritos sobre uma espécie em perigo. São Paulo: Graal, 1982.

COSTA, Kelly Sheila Inocêncio. A farsa da boa preguiça na sala de aula: o ideário cristão e o riso entre a cultura popular e a erudita. João Pessoa, 2006. Dissertação na área de Linguagem e Ensino, Curso de Pós-Graduação em Letras, Universidade Federal da Paraíba.

COSSON, Rildo. Letramento literário: teoria e prática. São Paulo: Contexto, 2006.

FOUCAULT, Michel. Vigiar e Punir: nascimento da prisão. Petrópolis: Vozes, 1987.

FREIRE, Paulo. A Importância do Ato de Ler: em três artigos que se completam. 22 ed. São Paulo: Cortez, 1988.

GROTOWSKI, Jerzy. Em busca de um teatro pobre. Rio de Janeiro: Civilização brasileira, 1992.

HUIZINGA, Johan. Homo ludens: o jogo como elemento da cultura. São Paulo: Perspectiva, 2007.

LEITE, Priscila Tatiana Araújo. Os jogos teatrais como recurso pedagógico: relato de experiência na Escola Parque 313/314 Sul, 2016.

MAREGA, Larissa Minuesa Pontes. A palavra em cena: o texto dramático no ensino de língua portuguesa. 262 f.Tese (Doutorado) - Faculdade de Filosofia, Letras e Ciências Humanas, Universidade de São Paulo, São Paulo, 2015.

MORIN, Edgar. Os sete saberes necessários a educação do futuro. Trad. de Catarina Eleonora F. da Silva e Jeanne Sawaya. 9. ed. São Paulo: Cortez, 2004.

MOISÉS, Massaud. A criação literária. São Paulo: Cultrix, 2000.

PERISSÉ, Gabriel. Literatura e Educação. Belo Horizonte: Autêntica, 2006.

SARRAZAC, Jean-Pierre. A invenção da teatralidade. Trad. Silvia Fernandes da Silva 
Telesi. Revista Sala Preta PPGAC. V.1, n. 13, 2013. Disponível em: https://doi. org/10.11606/issn.2238-3867.v13ilp56-70. Acesso em 09 de novembro de 2018.

SPOLIN, Viola. Jogos Teatrais para a sala de aula: um manual para o professor. Trad. Ingrid Dormien Koudela. São Paulo: Perspectiva, 2008.

SPOLIN,Viola. Jogos Teatrais: o fichário de Viola Spolin. Trad. Ingrid Dormien Koudela. São Paulo: Perspectiva, 2012.

SUASSUNA, Ariano. O santo e a porca. São Paulo: Nova Fronteira, 2018.

Mestre em História e Letras pela Universidade Estadual do Ceará (2019). Especialista em Literatura e Formação de Leitores pela Universidade Estadual do Ceará (2018). Graduada em Letras/ Língua Portuguesa Licenciatura pela Universidade Estadual do Ceará (2015). Tem experiência como professora da rede de ensino estadual do Ceará, atuando na área de Linguagens e códigos, com ênfase em Língua Portuguesa, Língua Espanhola e Artes. Desenvolvendo projetos nas áreas de Literatura, Literatura Brasileira, Poesia, Teatro e Gênero. Participante do Grupo de Pesquisa Literatura e as Metodologias para a Formação de Leitores e membro do Coletivo Feminista Severinas. E-mail: alyce9191@hotmail.com

\section{Maria Valdenia da SILVA}

Possui doutorado em Letras pela Universidade Federal da Paraíba (2008), mestrado em Letras pela Universidade Federal do Ceará (1997) e graduação em Letras pela Universidade Federal do Ceará (1993). Atualmente é professora Adjunta da Universidade Estadual do Ceará, atuando na graduação em Letras e no Mestrado interdisciplinar em História e Letras. Tem experiência nas áreas de ensino de literatura; crítica literária, letramento literário, literatura e outras linguagens e literatura e novas tecnologias. Participa como líder do Grupo Literatura e as Metodologias para a Formação de Leitores (UECE), do programa de extensão: Viva a palavra: circuitos de linguagem, paz e resistência da juventude negra na periferia de Fortaleza. E-mail: maria. valdenia@uece.br 